\title{
EFL Teachers' Perceptions and Practices of Information Literacy
}

\author{
Didik Syaifullah \\ Universitas Negeri Surabaya \\ Surabaya, Indonesia \\ didiksyaifulah@mhs.unesa.ac.id
}

\author{
Pratiwi Retnaningdyah \\ Universitas Negeri Surabaya \\ Surabaya, Indonesia \\ pratiwiretnaningdyah@unesa.ac.id
}

\author{
Lies Amin Lestari \\ Universitas Negeri Surabaya \\ Surabaya, Indonesia \\ lieslestari@unesa.ac.id
}

\begin{abstract}
This qualitative inquiry examined two English teachers' perceptions of information literacy (IL) in the secondary schools. The study sought to illuminate individuals' understanding, opinions or belief of information literacy. To collect data, semi-structured interviews were employed as the research instruments. The findings of this study indicated that the teachers had a lack familiarity with the term of IL. The factor that caused this finding is the term literacy particularly IL has been recently introduced to EFL teachers in Indonesia. Thus, it is obvious that the finding indicated that not all EFL teachers understand the term particularly who live in rural areas like the participating teachers. However, it was apparently shown from the interview data that teachers valued students' information need. All teachers interviewed were aware of how important the capability to find and use information was. They appreciated the need to prepare students to effectively cope with the abundant and diverse information available today. They also knew that students should be active information seekers or independent learners. In addition, they certainly see the merits of IL training hence they had adequate skills to teach students to seek information they needed independently.
\end{abstract}

\section{Keywords - Perceptions; Information Literacy; Secondary schools}

\section{INTRODUCTION}

Information Literacy, henceforth abbreviated as IL, has been an ongoing issue and concern in education today. This concern arises due to the development of information is produced not only through printed media such as books or newspapers but also through the electronic medium, e.g., websites, blogs, Facebook, electronic news and any other social and electronic media. A change in teaching approaches from behaviorist to constructivist has also contributed the importance of IL as it is defined as "as the ability to search, locate, evaluate and ultimately use information or facts, and thereafter create useful knowledge from it" [1]. Likewise, another definition by The Alexandria Proclamation advocated that IL empowers people in all aspects of life to seek, evaluate, use, and create information effectively to achieve their personal, social, occupational and educational goals [2].

At the same time, however, some researchers reported some weaknesses in students' IL. There is an acknowledgment that students cannot be expected to develop information literacy naturally on their own. The students mainly depend on teachers and textbooks as the main source of information. Whereas it is increasingly crucial that students learn to use information with respect with multiple resources available from printed texts [3] or search engines [4].

Therefore, based on the facts shown above, teaching IL is acquiring crucial importance. Numerous studies have also proposed that IL needs to be addressed formally and explicitly in teaching [5]. Teaching IL is one of attempts to construct literate students and environment and support life-long learning. Across countries, the development of IL is considered important for students since they need it for their life at school, from primary to tertiary level of education, for their private and working lives, as well as for their active participation in a democratic society [6].

Speaking of the development of literacy in Indonesia, Kementrian Pendidikan dan Kebudayaan (Ministry of Education and Culture, henceforth Kemendikbud or MOEC) sets a flagship program called Gerakan Literasi Sekolah (GLS). This literacy program is made as an initiative and implementation of Permendikbud Number 23 Year 2015 [7] and aims to cultivate children manners through cultural literacy (reading and writing). It also has an objective to train students to search and use information correctly and intelligently. This literacy teaching and learning had an emphasis to read and write is more applicable in elementary school (SD/MI) and Junior High School (SMP/MTs) [8]. In addition, they add an idea that learning literacy that includes learning to read and write basically requires the ability of learners in collecting, processing, and presenting information. These statements refer to the definition of IL and are further relevant with a statement that asserting IL skills are as essential as basic reading and writing [9].

In addition, the previous Indonesian curriculum schoolbased curriculum (CBC), well-known as Kurikulum Tingkat Satuan Pendidikan (KTSP) or the recently revised one, Curriculum $2013 / \mathrm{K}-13$, basically promote the IL teaching and practices in the classroom. Both curriculum have principles that encourage the teacher to facilitate the students to find out and 
learn from a variety of learning resources, to help them experience learning that promotes cultivation and empowerment of students as lifelong learners and to promote the use of information and communication technology to improve the efficiency and effectiveness of learning. In other words, the curriculums emphasize the importance of lifelong learning and independent learning.

However, unlike the neighboring countries such as Singapore, Malaysia, Australia which has embedded IL skills within their curriculum, EFL teachers in Indonesia need to develop the strategies on their own that promotes the students to be active-information seekers particularly in EFL classroom. The absence of any information literacy skill developments that should be carried out by the MOEC becomes another reason. Despite this circumstances, the information seeking which is regarded as the core of IL has been promoted with the use of scientific approach, henceforth SA, in K-13. Thus, this recognition underlies this research to explore IL practices in K13. In the New Literacy Study, literacy, particularly IL, is viewed as social practices that is how it is used and what people do with it in everyday life [10].

The SA comprises five steps of learning: they are observing, questioning, experimenting (collecting information), associating (reasoning) and communicating [11]. SA is used in entire subjects including English especially in junior and senior high school [12]. When EFL teachers implement SA, accessing information can be found in the instructional activities since they fit IL standards and indicators as shown in the table below.

Table 1: The Similarity of SA, The Big6 and E8 skills

\begin{tabular}{|c|c|c|}
\hline $\begin{array}{lr}\text { Scientific } & \text { Approach } \\
\text { (SA) of } 2013 \\
\text { Curriculum }\end{array}$ & The Big6 & Empowering 8 \\
\hline $\begin{array}{ll}\text { 1. } & \text { Observing } \\
\text { 2. } & \text { Questioning } \\
\text { 3. } & \text { Collecting } \\
\text { Information/Exper } \\
\text { imenting } \\
\text { 4. }\end{array}$ & $\begin{array}{ll}\text { 1. Task Definition } \\
\text { 2. Information } \\
\text { seeking } \\
\text { strategies } \\
\text { 3. Location and } \\
\text { access } \\
\text { 4. Use } \\
\text { information of } \\
\text { 5. Synthesis } \\
\text { 6. Evaluation } \\
\end{array}$ & $\begin{array}{ll}\text { 1. } & \text { Identify } \\
\text { 2. } & \text { Explore } \\
\text { 3. } & \text { Select } \\
\text { 4. } & \text { Organize } \\
\text { 5. } & \text { Create } \\
\text { 6. } & \text { Present } \\
\text { 7. } & \text { Assess } \\
\text { 8. } & \text { Apply }\end{array}$ \\
\hline
\end{tabular}

The curriculum 2013, moreover, based on Permendikbud No. 103 Year 2014 about the Standard Process also demands EFL teachers to apply the constructivist learning models such as Inquiry-based Learning, Discovery Learning, Project-based Learning and Problem-based Learning [13]. The EFL teachers will probably use learning models which help their students to be information literate. Teachers can create and design individual or group assignments that adapt or enhance to better promote IL goals and to better facilitate students' development to be independent learners. It is also stated that the implementation of different approaches and models will assist faculty to design and provide more effective IL education, and it can encourage students to develop "a more expansive repertoire" and improve "their learning outcomes" [14].

A previous research showed that Inquiry learning and Problem-based learning enhance learners' abilities to use information which involve students working in teams to gather and use information to inform solutions to complex problems [15]. Similarly, inquiry-based learning also provides an excellent context in which to develop students' IL knowledge and skills. Both PBL and inquiry learning require students to work on 'problems' in groups and trace information to successfully complete tasks. Another previous study investigating the teachers' understanding and practices suggests that teachers' practice of IL also be part of any future investigation since it will also provide very useful information about student knowledge and practice [5]. The study also found that although a number of New Zealand teachers did have some understanding of the concept of information literacy and connected it with literacy or with reading or information and communications technology (ICT), they were not explicitly teaching information literacy skills or providing inquiry learning opportunities, using an information process, for students.

Furthermore, since term of IL is relatively new in Indonesia, there is little research available addressing information literacy. Thus, the researcher views exploration on the teachers' perception as pivotal gap which is worth studying. This study will answer the following research question, how do the EFL teachers perceive Information Literacy (IL)?

\section{METHOD}

The research employed qualitative research design to explore and gain insight into Indonesian English teachers' perceptions of information literacy as the central phenomenon that require exploration and understanding [16]. The method used for the present study was collective case study because the researcher studied multiple cases at the same time to provide insight into the issue [17]. The cases were teachers' perceptions of IL. The research used purposive sampling since the idea of qualitative research is to purposefully select informants that best answer the research questions. [17].

Hence, the subjects of the research are two English teachers in EFL classrooms of two different level schools, junior and senior high school. The settings are those schools which are located in Paiton Probolinggo. To collect data, the researcher chose interview as it is normally used by qualitative researchers [18]. Interview is used to gather data from people about opinions, beliefs, and feelings about situations in their own words [19]. The interview themes are as follow.

\section{A. Gathering the EFL teachers' demographic information}

B. Asking participating EFL teachers to complete the statement "Information literacy is . . .". Their insight and definition on each word in the phrase are also taken into account.

\section{Exploring participants' beliefs about information literacy development.}

In this theme, the researcher asks a set of questions which will illustrate the teacher's attitudes and beliefs in two stages as follow:

- Teachers' awareness of students' needs of information

- Teachers' belief of scientific approach 
- Teachers' belief towards IL training

\section{FINDINGS AND DISCUSSION}

In examining how teachers perceive IL, it was essential to explore their views and opinions of IL as a concept, IL in K-13, and their attitudes and beliefs of it. To refer again to the concept of perceptions detailed in chapter II, perception was defined as an understanding, belief or opinion of the world constructed from information obtained by means of the senses [20]. Therefore, the findings in the following section were based on the Lewis' definition.

\section{A. Perceiving Information Literacy as a Concept}

The following data was provided based on the participating teachers' responses on the first question of the interview. When they were asked to express their opinion or understanding of IL, teacher A said:

"Ehm, [I got no idea] what it is. [Perhaps, it's] about books teachers used in the lesson [English] available in school or outside school". (Int-T1)

When the researcher confirmed whether she ever heard of the term information literacy, she said:

"I've never heard of it (Information Literacy". (Int-T1)

Apparently, a similar statement was echoed by the other participant of the research. She stated:

“Ehm, I don't know about it. I am not familiar with the term Information Literacy". (Int-T2)

Both participants indicated a lack of familiarity with the term of IL. Participants often looked away as they provided their view or understanding of IL. Before the interviews began, teachers often expressed somewhat excusatory statement such as "I don't know to answer your question". Moreover, the other teacher frankly asked the researcher to let her know what actually IL was after the interview.

As the interview was semi-structured, the researcher tried to ask them what they think of when they encounter the word 'information'. The teacher A, the junior high school teacher with over a decade of experience, defined it as:

"Yes, [information serves] as a supplement [of they have learned in the classroom]”. (Int-T1)

The other teacher indicated different conception related to it. She proposed a statement related to ICT practice and gave a somewhat true definition of IL when she said:

"If [I heard of the word] information, it usually [refers] to browsing". (Int-T2)
She also added some notion in defining the term literacy as she ever heard of it before from her colleague:

"I ever heard of the term of literacy from Indonesian teacher. That I know, literacy relates with reading, doesn't it?'”. (Int-T2)

The participants were hesitant of what actually IL was and admitted that they had not heard the term before yet all were willing to propose what their understanding of what the phrase may indicate in this literacy.

The findings of this study indicated that the teachers had little understanding of the term information literacy. Both participants indicated a lack of familiarity with the term of IL. In addition, the researcher tried to ask them what they think of when they encounter the word 'information'. The teacher A, the junior high school teacher with over a decade of experience, defined it as books. Meanwhile, the other teacher indicated different conception related to it. She proposed a statement related to ICT practice and gave a somewhat true definition of IL when she said the word accessing information through browsing information in the internet. She also added some notion in defining the term literacy as she ever heard of it before from her colleague. The literacy was defined as reading activity. Their conceptions of IL, books and reading, were not fit to the definition proposed by ALA nor Alexandria Proclamation which defined IL as "the ability to search, locate, evaluate and ultimately use information or facts, and thereafter create useful knowledge from it". They just indicated the resource of information and activity how information obtained. In addition, the participants were hesitant of what actually IL was and admitted that they had not heard the term before yet all were willing to propose what their understanding of what the phrase may indicate in this literacy.

These finding might led to an assumptions or claim that the participating teachers would not likely to accommodate IL practices in their classroom. It was supported by numerous studies that found teachers' practices of IL teaching are influenced by their conceptions of (information literacy) learning [21]. In addition, teachers' IL skills may be low and thus they were not aware of or did not understand these skills. Due to their own potentially low IL proficiency, teachers were not likely to teach these skills to their students [22] .

\section{Teachers' Beliefs of Information Literacy}

In this subchapter, the participants' beliefs or opinions were explored since their perception could be illustrated from this aspect.

a. Teachers' Awareness of Students' Needs of Information All teachers interviewed were aware of how important the capability to find and use information was. They appreciated the need to prepare students to effectively cope with the abundant and diverse information available today.

"Students should have additional literacy in addition [information /knowledge] from school like the knowledge from internet". (Int-T1) 
They also knew that students should be active information seekers. Teacher A thought that it was essential for students to follow some seminars.

"[Sure], students should be active [to seek information] to acquire more knowledge. Literacy is not just from books but also from seminars. It was also needed". (Int-T1)

Meanwhile, teacher B showed her awareness by giving statement that students nowadays should be "independent" in locating information for their study. It was thus necessary for them to "be active in the learning process" particularly in English classroom and equip themselves with "ICT operational skills".

Furthermore, the findings for the first research question about teachers' attitudes and beliefs of IL indicated that the participating teachers had shown well-awareness of their students' needs of information. One of the teachers frankly asked the researcher to let her know what actually IL was after the interview. All teachers interviewed were aware of how important the capability to find and use information was. They appreciated the need to prepare students to effectively cope with the abundant and diverse information available today. They also knew that students should be active information seekers. Teacher A thought that it was essential for students to follow some seminars. Meanwhile, teacher B showed her awareness by giving statement that students nowadays should be "independent" in locating information for their study. It is thus necessary for them to "be active in the learning process" particularly in English classroom and equip themselves with "ICT operational skills".

b. Teachers' Beliefs towards the Students' Accessing Information Skills in SA

They had, however, different attitudes about the implementation of SA in the school setting. They had lack of beliefs towards SA implementation since they encounter barriers when it comes to teaching using SA essential skills, identifying and exploring information needed. All respondents supported the idea that the initial steps of SA "is is probably rather difficult" concerning the following reasons.

"The students are difficult [to seek information] by themselves because the information is obtained from teachers". (Int-T1)

"Sometimes using SA is less-effective since students like accessing social media such as facebook. So the time was spent in vain". (Int-T2)

They had different attitudes about the implementation of SA in the school setting. They had lack of beliefs towards SA implementation since they encounter barriers when it comes to teaching using SA essential skills, identifying, exploring and evaluating information needed. All respondents supported the idea that the initial steps of SA is rather difficult concerning the students did not have adequate skills to seek information they needed independently. This finding were consistent with the previous studies which revealed that students lack IL skills, especially those skills associated with the critical evaluation of sources [9].

\section{c. Teachers' Belief towards IL Training}

The finding disclosed that respondents also argued that the responsibility for teaching IL as well as scientific approach should be assigned to teachers. Later on, they expected to be involved in proper training.

"The ideal situation is teachers should be obliged to join trainings that increase their teaching competence. They should join seminar or workshop". (Int-T1)

"I believe that teachers have to do this task. They should always want to increase their qualification". (Int-T2)

One participant supported the idea of creating a team that could provide teachers proper training, as it has been done in 2013 curriculum.

"I think that government should assign qualified teachers in information literacy teachers to train other teachers just like what they did in 2013 curriculum". (Int-T2)

The findings of the research also revealed that respondents argued the responsibility for teaching IL as well as scientific approach should be assigned to teachers. In the following days they expected to be involved in proper training. One participant supported the idea of creating a team that could provide teachers proper training, as it has been done in 2013 curriculum. Their interest of IL training was consistent with many teachers interviewed by Probert [23]. He stated how much teacher would welcome appropriate training in order to help their students develop better skills. Apart from the absence of IL-specific training, other problems encountered by teachers in their efforts to implement IL teaching were lack of time, urgent need to cover the prescribed material and prepared students for exams, low computer-student ratio particularly the MTs students and unstable network connection.

In conclusion, the findings of this study indicated that the teachers had a lack familiarity with the term of IL. The factor that caused this finding is the term literacy particularly IL has been recently introduced to EFL teachers in Indonesia. Thus, it is obvious that the finding indicated that not all EFL teachers understand the term particularly who live in rural areas like the participating teachers. However, it was apparently shown from the interview data that teachers valued students' information need. All teachers interviewed were aware of how important the capability to find and use information was. They appreciated the need to prepare students to effectively cope with the abundant and diverse information available today. They also 
knew that students should be active information seekers or independent learners. In addition, they certainly see the merits of IL training hence they had adequate skills to teach students to seek information they needed independently.

\section{REFERENCES}

ALA, "Presidential Committee on Information Literacy: Final Report," $1989 . \quad$ [Online]. Available: http://www.ala.org/acrl/publications/whitepapers/presidential. [Accessed: 25-Jan-2017].

[2] S. D. Garner, "High-Level colloquium on information literacy and lifelong learning," Alexandria, 2006.

[3] D. Barton, M. Hamilton, and R. Ivanič, Situated Literacies; Reading and Writing in Context. London: Routledge, 2000.

[4] V. Sieber, J. Anthoney, H. Barker, and E. Roberts, "Chapter 15 Information Literacy in a Digital Age: Embedding Information Literacy in the Curriculum," in The End of Wisdom?, W. Evans and D. Baker, Eds. Cambridge: Elsevier Science \& Technology, 2017, pp. $135-140$

[5] E. Probert, "Information literacy skills: Teacher understandings and practice," Comput. Educ., vol. 53, no. 1, pp. 24-33, 2009.

[6] N. Mertes, "Teachers ' Conceptions of Student Information Literacy Learning and $\mathrm{T}$ eachers' Practices of Information Literacy Teaching and Collaboration with the School Library: A Grounded Case Study," Humboldt-Universität zu Berlin, 2014.

[7] Kemendikbud, "Peraturan Menteri Pendidikan dan Kebudayaan Republik Indonesia Nomor 23 Tahun 2015 tentang Penumbuhan Budi Pekerti." Kemendikbud, Jakarta, pp. 1-8, 2015.

[8] K. Laksono et al., "Manual Pendukung Pelaksanaan Gerakan Literasi Sekolah Untuk Jenjang Sekolah Menengah Pertama," Jakarta, 2016.

[9] H. Julien and S. Barker, "How high-school students find and evaluate scientific information: A basis for information literacy skills development," Libr. Inf. Sci. Res., vol. 31, no. 1, pp. 12-17, 2009.

[10] K. Pahl and J. Rowsell, Literacy and Education. London: Paul Chapman Publishing, 2005.

[11] Kemendikbud, Materi Pelatihan Implementasi Kurikulum 2013. Jakarta: Badan Pengembangan Sumber Daya Manusia Pendidikan dan Kebudayaan dan Penjaminan Mutu Pendidikan, 2014.

[12] K. Pendidikan and D. A. N. Kebudayaan, "Tema Pengembangan Kurikulum 2013," no. September, 2013.

[13] Kemendikbud, "Salinan Lampiran Peraturan Menteri Pendidikan dan Kebudayaan Republik Indonesia Nomor 103 Tahun 2014 Tentang Pembelajaran Pada Pendidikan Dasar dan Pendidikan Menengah." Kemendikbud, Jakarta, 2014.

[14] R.-A. Diehm and M. Lupton, "Approaches to Learning Information Literacy: A Phenomenographic Study," J. Acad. Librariansh., vol. 38, no. 4, pp. 217-225, 2012

[15] L. Dodd, "The Impact of Problem-Based Learning on the Information Behavior and Literacy of Veterinary Medicine Students at University College Dublin," J. Acad. Librariansh., vol. 33, no. 2, pp. 206-216, 2007.

[16] J. W. Creswell, Educational research: Planning, conducting, and evaluating quantitative and qualitative research, 4 th ed. Boston: Pearson Education, Inc., 2012.

[17] J. R. Fraenkel, N. E. Wallen, and H. H. Hyun, How to Design and Evaluate Research in Education, 8th editio. New York: McGraw Hill Companies, 2012.

[18] A. L. Strauss and J. M. Corbin, Basics of Qualitative Research: Techniques and Procedures for Developing Grounded Theory, 2nd ed. Thousand Oaks, California: Sage Publications, Inc., 1998.

[19] D. Ary, L. C. Jacobs, and C. Sorensen, Introduction to Research in Education, 8th editio. Belmont, CA: Wadsworth, Cengage Learning, 2010.

[20] A. Lewis, "The Issue of Perception: Some Education Implications," Educare, vol. 30, no. 1, pp. 272-288, 2001.

[21] C. Bruce, S. Edwards, and M. Lupton, "Six Frames for Information literacy Education: a conceptual framework for interpreting the relationships between theory and practice.," Innov. Teach. Learn. Inf. Comput. Sci., vol. 5, no. 1, pp. 1-18, 2006.

[22] P. Moore, "An analysis of information literacy education worldwide in School," Libr. Worldw., vol. 11, no. 2, pp. 1-23, 2005.

[23] E. Probert, "The important role of information literacy and learning in the development of lifelong learners: How well prepared are our teachers and students?," in the 37th Annual Conference of the International Association of School Librarianship and the Twelfth International Forum on Research in School Librarianship, 2008 